\title{
Kepentingan Sistem Maklumat Geografi (GIS) dan Penderiaan Jauh dalam Pemeliharaan Habitat Populasi Burung Hijrah di Hutan Paya Laut Matang, Perak \\ (The Importance of Geographic Information System (GIS) and Remote Sensing in Protecting Migratory Bird Habitat Population at Matang Mangrove Forest, Perak)
}

\author{
AZIMAH ABD RAHMAN*
}

\begin{abstract}
ABSTRAK
Kedatangan spesies burung hijrah ke Hutan Paya Laut Matang, Perak merupakan suatu fenomena unik dan amat berpotensi untuk dikomersialkan. Namun begitu sejak sepuluh tahun kebelakangan ini kedatangan spesies burung hijrah ke kawasan ini mencatatkan penurunan yang membimbangkan. Pembangunan di sekitar kawasan Hutan Paya Laut Matang dikenal pasti menjadi faktor utama penurunan ini. Selain itu, pengurusan dan pemantauan terhadap spesies burung hijrah yang tidak bersistematik juga menyumbang kepada permasalahan ini. Kaedah pengurusan dan pemantauan burung hijrah secara konvensional masih diamalkan oleh Jabatan Hidupan Liar dan Taman Negara (PERHILITAN) dalam merekod data dan maklumat yang diperoleh. Oleh itu kajian ini dilakukan dengan memperkenalkan pendekatan teknologi Sistem Maklumat Geografi (GIS) dan Penderiaan Jauh sebagai aplikasi utama yang dapat membantu dalam memperbaiki pengurusan dan pemantauan burung hijrah. Aplikasi GIS digunakan dalam memetakan data parameter kajian yang diperoleh menggunakan perisian yang bersesuaian iaitu ArcGIS 10.1 dan Penderiaan Jauh digunakan untuk memodelkan parameter kajian menggunakan aplikasi dalam perisian ERDAS Imagine 8.5. Sebanyak enam parameter kajian digunakan dalam kajian ini iaitu suhu, taburan hujan, makanan, ketinggian, gunatanah dan liputan tanah. Pemodelan setiap parameter kajian ini membolehkan kesan setiap parameter kajian terhadap taburan burung hijrah dalam suatu kawasan ditunjukkan dalam bentuk pemetaan. Hasil pemodelan ini juga membolehkan parameter yang terpenting dan paling mempengaruhi taburan burung hijrah bagi kawasan Hutan Paya Laut Matang dikenal pasti. Maklumat ini membolehkan DWNP lebih memahami keperluan burung hijrah dalam pemilihan habitat mereka. Selain itu, hasil pemodelan ini membantu DWNP dalam mengatur strategi pelaksanaan program pemeliharaan dan pemuliharaan di kawasan sekitar Hutan Paya Laut Matang bagi memastikan kedatangan spesies burung hijrah secara berterusan.
\end{abstract}

Kata kunci: ArcGIS 10.1; burung hijrah; ERDAS Imagine 8.5; Hutan Paya Laut Matang; Penderiaan Jauh; Perak; Sistem Maklumat Geografi (GIS)

\section{ABSTRACT}

The arrival of migratory bird species to Matang Mangrove Forest, Perak is a unique phenomenon and has a great potential for commercialization. However, for the last ten years the arrival of migratory bird species to this area has alarmingly decline. The development around Matang Mangrove Forest was identified as the main factor of this problem. Then, the lack of management and monitoring of migratory bird species that are not systematic enough also contribute to this problem. Conventional method still practiced in survey and bird monitoring by the Department of Wild Life and National Park (PERHILITAN) for data and information recorded purposes. Therefore, this study is needed to introduce the Geographic Information System (GIS) and Remote Sensing technology as the main approach that can help in improving the management and monitoring of migratory birds. GIS applications were used in mapping data of study parameters that were collected using the appropriate software like ArcGIS 10.1 and remote sensing was used to model the parameter study using ERDAS Imagine 8.5 software. Six parameters was used in this study including temperature, rainfall, food, elevation, land use and land cover. Parameters modeling are able to show the distribution of migratory bird in certain location using mapping interpretation. The result of this modeling help to identify the important parameter that affect the migratory bird distribution in Matang Mangrove Forest. This information also enables DWNP to understand more about migratory bird needs in their habitat selection. Besides that, this modeling result can assist DWNP to set up an implementation strategy to protect and preserve Matang Mangrove Forest in ensuring continuous arrival of migratory bird in future.

Keywords: ArcGIS 10.1; ERDAS Imagine 8.5; Geographic Information System (GIS); Matang Mangrove Forest; migratory bird; Perak; Remote Sensing 


\section{Pengenalan}

Burung hijrah merupakan spesies burung air yang berhijrah dari negara asal untuk mendapatkan perlindungan, makanan dan tempat tinggal sementara bagi meneruskan kehidupan. Selain itu, Burung hijrah juga memilih kawasan berhampiran air sebagai habitatnya (Howes et al. 2003). Elemen air amat penting sebagai penunjuk arah bagi meneruskan penerbangan mereka sepanjang musim hijrah dan seterusnya kembali ke negara asal apabila tiba masanya (Ahola et al. 2007). Di Malaysia, lokasi berpaya menjadi tumpuan bagi spesies burung ini sebagai habitat sementara mereka bagi mendapatkan bekalan makanan dan perlindungan sebelum meneruskan penghijrahan ke kawasan lain (Alongi 2002).

Terdapat beberapa kawasan berpaya yang menjadi tempat persinggahan spesies burung hijrah antaranya kawasan Hutan Paya Laut Matang yang menjadi tumpuan pelbagai spesies burung hijrah. Namun begitu, sejak sepuluh tahun kebelakangan ini kedatangan spesies burung ini telah mencatatkan penurunan yang dianggarkan antara 75 dan 95\% seperti yang telah direkodkan oleh Wetland International ( $\mathrm{Li}$ et al. 2009). Aktiviti pembangunan, pembalakan, pertanian dan pelbagai aktiviti ekonomi masyarakat setempat di sekitar kawasan Hutan Paya Laut Matang dikenal pasti menjadi punca utama penurunan bilangan populasi burung hijrah yang dicatatkan setiap tahun (Eng et al. 1989). Perkara ini menunjukkan kebergantungan spesies burung hijrah terhadap kawasan paya laut sebagai habitat pilihan mereka (Howes et al. 2003).

Sebagai tindakan, Jabatan Perhilitan bertanggungjawab penuh dalam memantau dan memerhati kedatangan spesies burung hijrah yang datang ke Hutan Paya Laut Matang setiap tahun. Musim hijrah yang singkat iaitu bermula dari bulan September dan berakhir pada April tahun berikutnya memerlukan pelan pelaksanaan program pemeliharaan dan pemuliharaan kawasan sekitar Hutan Paya Laut Matang yang lebih serius (Studd \& Marra 2004). Aktiviti menjaring burung hijrah dilakukan pada stesen yang dikenal pasti menjadi singgahan burung hijrah setiap tahun (Rahmah 2009). Data penting yang mengandungi maklumat terperinci berkaitan burung hijrah, lokasi habitat, jenis flora dan fauna sekeliling habitat dan lain- lain diperlukan dalam menjayakan program ini (Gauthreaux \& Belser 2003).

Namun begitu, kaedah konventional masih digunakan oleh Jabatan Perhilitan dalam proses pengumpulan data menyebabkan pelaksanaan program pemeliharaan dan pemuliharaan habitat burung hijrah menjadi kurang efektif. Pendekatan teknologi yang lebih efisien dan bersistematik diperlukan bagi memastikan kedatangan burung hijrah secara berterusan ke Hutan Paya Laut Matang. Kajian ini dijalankan dengan menggunakan pendekatan teknologi Sistem Maklumat Geografi (GIS) dan Penderiaan. Penggunaan aplikasi ini memudahkan pengurusan dan kemaskini data khususnya berkaitan burung hijrah dan persekitarannya (Mitchell et al.2001). Hasil analisis dalam bentuk piksel membolehkan analisis dan interpretasi data dilakukan dengan lebih menyeluruh dan tepat kerana tidak hanya tertumpu pada sesuatu lingkungan kawasan yang kecil sahaja tetapi menganalisis secara menyeluruh iaitu melibatkan lingkungan kawasan yang lebih luas (Richards \& Jia 1999).

\section{METODOLOGI KAJIAN}

\section{KAWASAN KAJIAN}

Kajian ini menumpukan kawasan Hutan Paya Laut Matang yang terletak di antara latitud $4^{\circ} 15^{\prime}-5^{\circ} 1^{\prime} \mathrm{N}$ dan longitud $100^{\circ} 2^{\prime}-100^{\circ} 45^{\prime} \mathrm{E}$ dengan keluasan keseluruhan yang meliputi kawasan laluan air sebanyak 40466 ha seperti Rajah 1 (Muda \& Mustafar 2008).

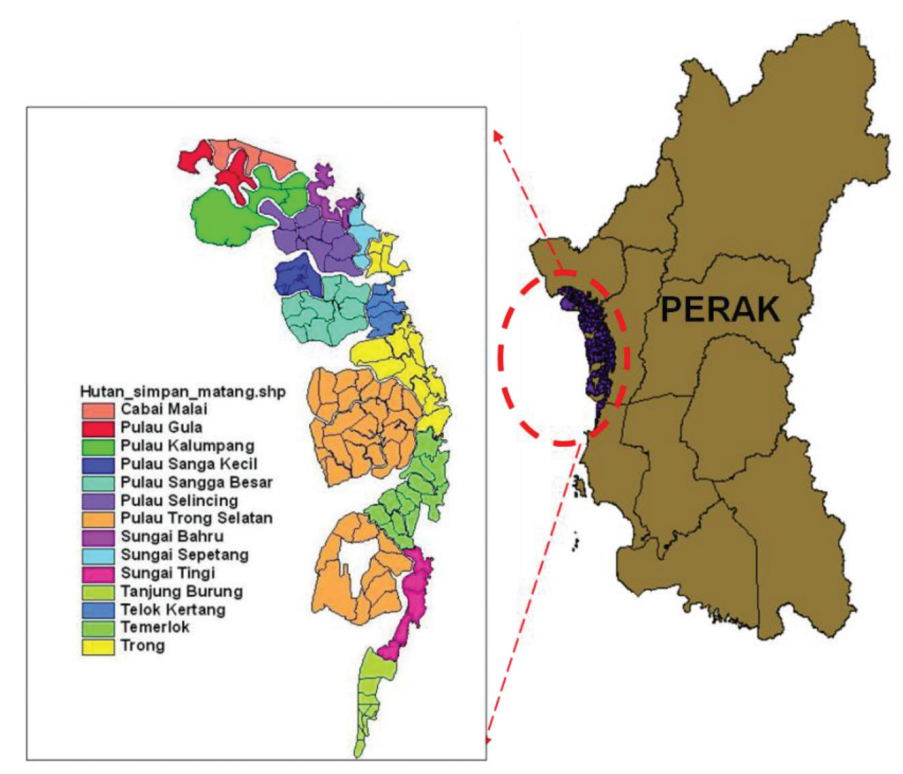

RAJAH 1. Kawasan Hutan Paya Laut Matang 


\section{DATA KAJIAN}

Data berkaitan burung hijrah merupakan data terpenting dalam kajian ini yang diperoleh melalui aktiviti pemerhatian dan pemantauan kedatangan burung hijrah yang dilakukan pada 10 stesen utama. Kesemua stesen ini dikenal pasti menjadi lokasi tumpuan burung hijrah melalui catatan kedatangan tertinggi yang direkodkan setiap kali musim hijrah oleh Jabatan Perhilitan. Jaringan pada setiap stesen dilakukan secara berkala iaitu sebanyak tiga sesi sepanjang musim migrasi burung hijrah antara bulan September dan April setiap tahun (Jadual 1).

JADUAL 1. Stesen jaringan burung hijrah

\begin{tabular}{lc}
\hline Kawasan tumpuan & Bilangan burung \\
\hline Kuala Gula & 200,556 \\
Kuala Selinsing & 77,723 \\
Kelumpang & 108.013 \\
Tasik Kelumpang & 71,164 \\
Tasik Trong & 46,644 \\
Parit Besar & 16,696 \\
Sungai Burung & 29,532 \\
Pantai Remis & 65,470 \\
Sungai Tiang & 32,532 \\
Sangga Besar & 49,227 \\
\hline
\end{tabular}

Selain itu, data sedia ada daripada pelbagai agensi yang berkaitan seperti JUPEM, Jabatan Meteorologi, Jabatan Perhutanan serta Jabatan Perancang Bandar dan Wilayah juga digunakan sebagai data sokongan dalam kajian ini. Keseluruhan data dalam kajian ini menggunakan format yang sama bagi memudahkan analisis data menggunakan perisian ArcGis 10.1 (Jadual 2).

\section{MODEL PARAMETER KAJIAN}

Matlamat pemodelan parameter dalam kajian ini adalah untuk mengenal pasti pengaruh setiap parameter kajian terhadap corak taburan burung hijrah. Melalui pemodelan ini, parameter terpenting yang mempengaruhi pemilihan lokasi habitat burung hijrah di sekitar Hutan Paya Laut Matang dikenal pasti. Pelaksanaan model ini melibatkan beberapa aliran kerja yang melibatkan proses pembahagian data mengikut kategori parameter, penetapan prasyarat bagi pembinaan model, penentuan pemberat model, pengelasan kepadatan burung hijrah mengikut piksel, penghasilan pemetaan dan menentusahkan parameter kajian yang terpenting (Rajah 2).

Bagi pemodelan parameter kajian, data yang berkaitan parameter kajian yang dikenal pasti mempengaruhi taburan burung hijrah sekitar Hutan Paya Laut Matang digunakan. Enam parameter telah digunakan iaitu suhu, hujan, makanan, liputan hutan, gunatanah dan ketinggian. Parameter dikelaskan kepada 3 bahagian mengikut kategori utama iaitu persekitaran, iklim dan keadaan topografi bagi memudahkan analisis dilakukan seperti Jadual 3 (Schaub et al. 2001).

Kajian ini menggunakan pendekatan aplikasi GIS berasaskan piksel dengan bantuan aplikasi Penderiaan Jauh. Oleh yang demikian, kesemua data parameter yang digunakan khususnya data satelit seperti data Resolusi Sederhana Pengimejan Spektroradiometer (MODIS), Misi Pengiraan Curahan Hujan Tropika (TRMM) dan Misi Topografi Radar Ulang-alik (SRTM) yang tersedia dalam bentuk piksel menggunakan saiz piksel yang sama dengan bantuan perisian ERDAS Imagine 8.5. Saiz piksel yang berkeluasan $50 \times 50 \mathrm{~m}$ digunakan dalam kajian ini. Penggunaan saiz ini adalah bersesuaian dengan saiz setiap stesen jaringan burung yang telah ditetapkan oleh Jabatan Perhilitan iaitu sebanyak $500 \times 500$ m, kesediaan data satelit dan skala besar yang digunakan dalam kajian ini iaitu 1:25000 kerana melibatkan liputan kawasan yang kecil.

Data parameter kajian dihubungkan antara satu sama lain melalui prasyarat yang merupakan ramalan atau kebarangkalian yang mungkin wujud sekiranya berlaku sebarang perubahan pada satu atau lebih parameter terhadap taburan burung hijrah. Penetapan prasyarat dilakukan berasaskan kerja lapangan yang dilakukan iaitu dengan mengenal pasti keadaan persekitaran, iklim

JADUAL 2. Antara data yang digunakan dalam kajian

\begin{tabular}{llc}
\hline Senarai data & Sumber data & Format data \\
\hline Lokasi kawasan kajian & Majlis Daerah Kerian & Ruangan \\
Data burung hijrah & Jabatan Perhilitan dan Hidupan Liar, Kuala Gula & Ruangan \\
Data fauna & Jabatan Perhilitan dan Hidupan Liar, Kuala Gula & Ruangan \\
Data kawasan menjaring & Jabatan Perhilitan dan Hidupan Liar, Kuala Gula & Ruangan \\
Data aktiviti ekonomi & Jabatan Perancang Bandar dan Desa Daerah Kerian & Ruangan \\
Data suhu & Jabatan Meteorologi Malaysia & Ruangan \\
Data hujan & Jabatan Meteorologi Malaysia & Ruangan \\
Data sungai & Jabatan Perhutanan Malaysia & 2000 -2000 \\
Data sempadan & Jabatan Perhutanan Malaysia & $2000-2009$ \\
Data ketinggian & Jabatan Perhutanan Malaysia & $2000-2009$ \\
Data kompartment hutan & Jabatan Perhutanan Daerah Larut Matang Ruangan \\
Data jenis hutan & Jabatan Perhutanan Daerah Larut Matang & $2000-2009$ \\
Data sempadan hutan & Jabatan Perhutanan Daerah Larut Matang & $2000-2009$ \\
\hline
\end{tabular}




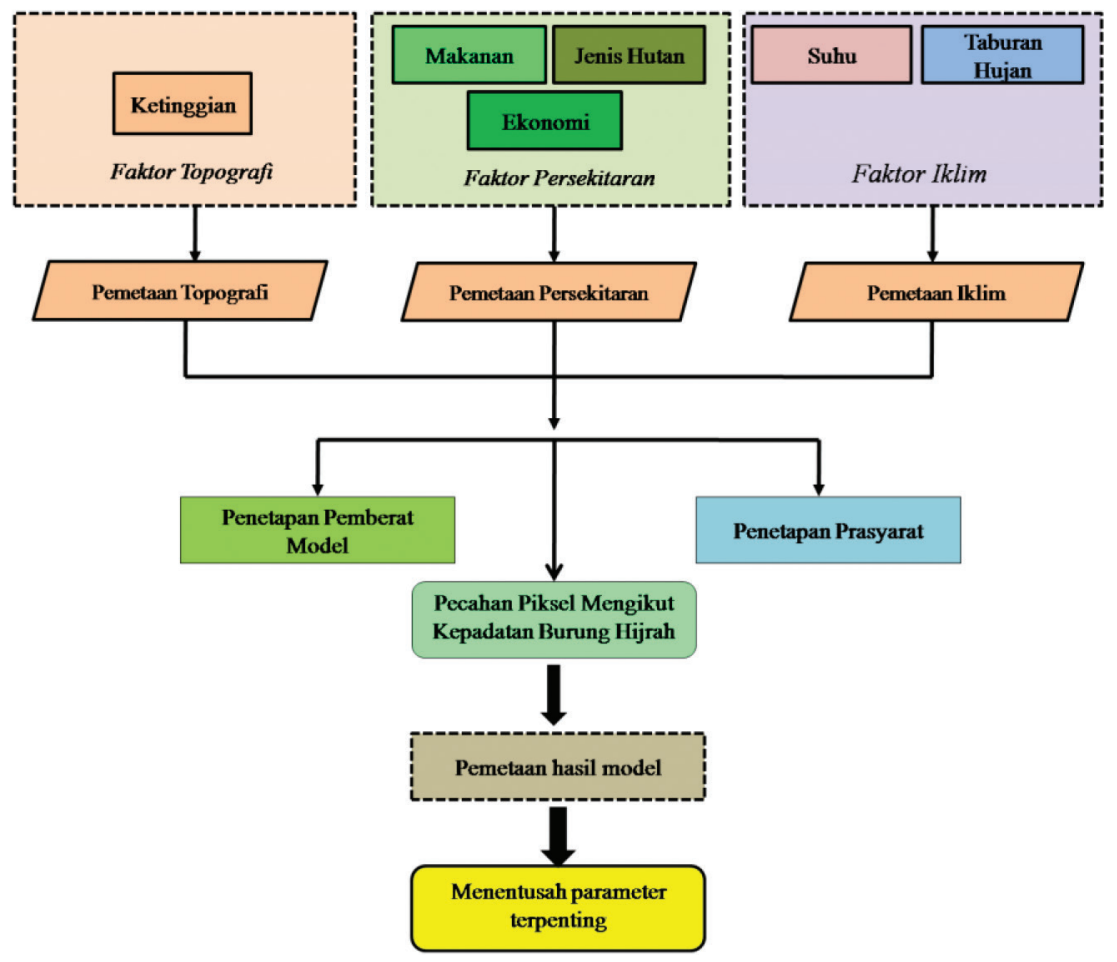

RAJAH 2. Aliran kerja pemodelan

JADUAL 3. Pembahagian mengikut kategori

\begin{tabular}{lll}
\hline Kategori parameter & Parameter & \multicolumn{1}{c}{ Jenis data } \\
\hline \multirow{3}{*}{ Persekitaran } & Makanan & \\
& Jenis hutan & Pemerhatian di lapangan dan hasil pensampelan (jaringan burung) \\
& Aktiviti ekonomi & \\
& Taburan Hujan & Moderate Resolution Imaging Spectrometer (MODIS) \\
Iklim & Suhu & Tropical Rainfall Measuring Mission (TRMM) \\
Topografi & Ketinggian & Shuttle Radar Topographic Mission (SRTM) \\
\hline
\end{tabular}

dan ketinggian kawasan yang mempunyai taburan burung hijrah yang tertinggi hingga yang terendah. Sebanyak lima prasyarat telah dibina berasaskan kepadatan burung hijrah bagi membantu pembinaan model (Jadual 4).

Selain itu, data kepadatan burung hijrah diwakilkan menggunakan pecahan piksel warna yang berbeza-beza mengikut tahap kepadatan burung hijrah. Penetapan pengelasan setiap pecahan piksel adalah menggunakan kaedah korelasi berasaskan bilangan kepadatan burung hijrah yang telah direkodkan di lapangan (Jadual 5).

Pengelasan ini akan digunakan sebagai asas dalam pembinaan pemetaan pengaruh setiap parameter kajian terhadap kepadatan populasi burung hijrah. Hasil korelasi menunjukkan kepadatan burung hijrah yang terendah diwakilkan sebagai warna biru manakala warna merah menunjukkan kepadatan burung hijrah yang tertinggi.

JADUAL 4. Prasyarat pemodelan parameter kajian

\begin{tabular}{|c|c|c|c|c|c|c|}
\hline & \multirow{2}{*}{$\begin{array}{l}\text { Parameter ketinggian } \\
\text { Ketinggian } \\
(\mathrm{m})\end{array}$} & \multicolumn{3}{|c|}{ Parameter persekitaran } & \multicolumn{2}{|c|}{ Parameter iklim } \\
\hline & & Liputan tanah & Makanan & Gunatanah & $\begin{array}{l}\text { Suhu } \\
\left({ }^{\circ} \mathrm{C}\right)\end{array}$ & $\begin{array}{c}\text { Taburan hujan } \\
(\mathrm{mm})\end{array}$ \\
\hline Sangat Rendah & $20-25$ & $2,3,4,5,6,7$ & 2 & 3 & $16-18,30-31$ & $1251-1261$ \\
\hline Rendah & $>25$ & $3,4,6$ & 3 & 2 & 19-20 & $1226-1237$ \\
\hline Pertengahan & $11-15$ & $2,3,5,6$ & 4 & 1 & $21-23$ & $1238-1246$ \\
\hline Tinggi & $16-20$ & $2,5,6$ & 5 & 1 & $24-26$ & $1217-1232$ \\
\hline Sangat Tinggi & $0-15$ & 5,6 & 6 & 4 & $27-29$ & $1262-1277$ \\
\hline
\end{tabular}


JADUAL 5. Perwakilan kepadatan burung hijrah

\begin{tabular}{ccc}
\hline $\begin{array}{c}\text { Kepadatan keseluruhan } \\
\text { burung hijrah }\end{array}$ & Nilai kelas & Jenis kelas \\
\hline 15 & & \\
19 & & \\
30 & 25.25 & Sangat rendah \\
37 & & \\
100 & 129.6667 & \\
130 & & \\
159 & & \\
236 & & \\
268 & 273.6 & \\
282 & & Sederhana \\
285 & & Tinggi \\
297 & & \\
367 & & Sangat tinggi \\
376 & & \\
447 & 1445 & \\
497 & & \\
735 & & \\
2155 & & \\
\hline
\end{tabular}

Penggunaan warna yang berbeza mengikut tahap kepadatan burung hijrah memudahkan pemahaman hasil pemetaan yang dilakukan (Jadual 6).

Kepentingan sesuatu parameter kajian dalam pembinaan model ini dibahagikan mengikut pemberat. Setiap pemberat akan menunjukkan tahap kepentingan dan pengaruh setiap parameter terhadap kepadatan burung hijrah dalam sesuatu kawasan. Pemberat keseluruhan bagi setiap parameter dianggap 100\% dan setiap satu parameter mempunyai pengaruh yang sama. Oleh kerana terdapat tiga kategori parameter, setiap parameter dianggap mempunyai peratus kepentingan 33\% (Jadual 7).

Aplikasi Knowledge Classifier dan Knowledge Engineer dalam perisian ERDAS Imagine 8.5. digunakan dalam memodelkan setiap parameter kajian menggunakan pemberat yang telah ditetapkan (Rouget et al. 2003). Menggunakan aplikasi ini, setiap parameter akan dihubungan dengan setiap prasyarat kajian dalam bentuk diagram yang mudah dikemaskini dan difahami (Rajah 3).

JADUAL 6. Pengelasan kepadatan burung hijrah

\begin{tabular}{lcc}
\hline Pengelasan & Kepadatan burung hijrah & Perwakilan \\
\hline Sangat rendah & 25 burung per $50 \mathrm{~m}^{2}$ \\
Rendah & 130 burung per $50 \mathrm{~m}^{2}$ \\
Sederhana & 274 burung per $50 \mathrm{~m}^{2}$ \\
Tinggi & 422 burung per $50 \mathrm{~m}^{2}$ \\
Sangat tinggi & 1445 burung per $50 \mathrm{~m}^{2}$ & \\
\hline
\end{tabular}

JADUAL 7. Pemberat model

\begin{tabular}{lcc}
\hline Parameter & Pemberat keseluruhan & Pemberat / parameter \\
\hline Suhu & \multirow{2}{*}{0.33} & 0.17 \\
Taburan hujan & & 0.17 \\
Liputan tanah & 0.33 & 0.11 \\
Gunatanah & & 0.11 \\
Makanan & \multirow{2}{*}{0.33} & 0.11 \\
Ketinggian & & 0.33 \\
\hline
\end{tabular}




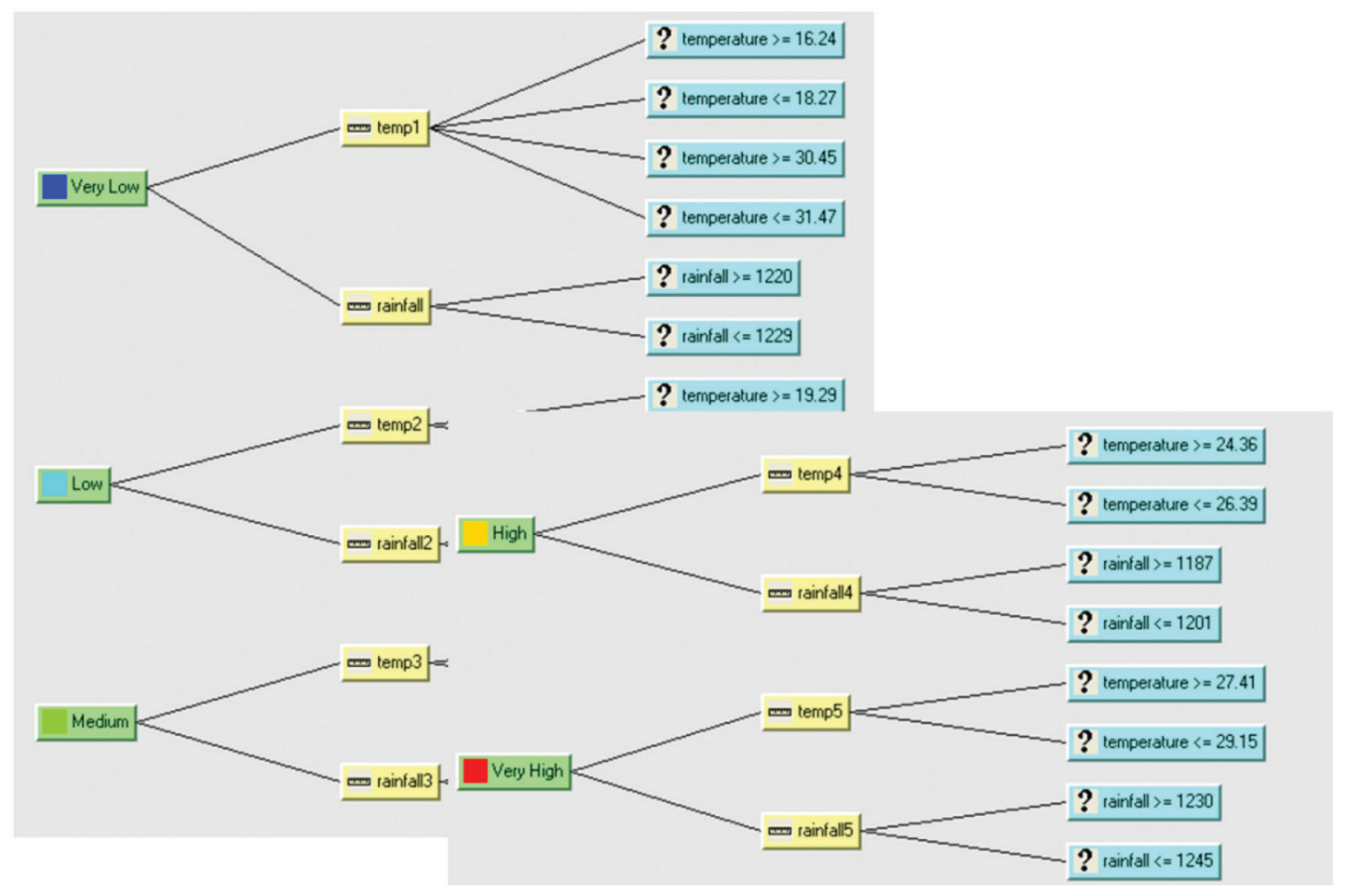

RAJAH 3. Hubungan parameter kajian

\section{HASIL KAJIAN DAN PERBINCANGAN}

\section{PEMETAAN PERSEKITARAN}

Pemodelan faktor persekitaran bagi kajian ini menunjukkan hubungan antara perubahan persekitaran yang meliputi pelbagai aktiviti ekonomi masyarakat setempat atau gunatanah, liputan tanah dan sumber makanan yang tersedia dalam sesuatu kawasan terhadap kepadatan burung hijrah (Rajah 4).

Hasil pemetaan persekitaran yang diperoleh menunjukkan beberapa kawasan yang berhampiran dengan laut menjadi tumpuan burung hijrah. Antaranya kawasan Kuala Gula, Pulau Kalumpang, Pulau Selinsing dan sebahagian kecil kawasan Pulau Sangga Kecil menjadi tumpuan utama bagi burung hijrah iaitu sebanyak 1445 ekor per $50 \mathrm{~m}^{2}$ yang meliputi 14\% daripada keluasan keseluruhan Hutan Paya Laut Matang. Beberapa kawasan yang menghampiri daratan seperti kawasan Sungai Bahru, Sungai Sepetang, Trong, Temerlok dan Sungai Tinggi menunjukkan kepadatan burung hijrah yang sangat rendah iaitu sebanyak 25 ekor per $50 \mathrm{~m}^{2}$ yang meliputi $5 \%$ daripada keluasan keseluruhan kawasan Hutan Paya Laut Matang.

Kawasan sekitar Kuala Gula, Cabai Malai, Pulau Kalumpang dan Pulau Sanggar Kecil juga mempunyai persekitaran yang majoritinya diliputi oleh tumbuhan bakau daripada spesies Rhizophora spp. (Bakau Kurap) yang merangkumi hampir $73 \%$ daripada kawasan keseluruhan Hutan Paya Laut Matang dan tumbuhan bakau daripada spesies Avicennia spp. (Bakau Api-api) yang meliputi $9 \%$ daripada kawasan ini. Struktur akar yang padat dan rapat menyediakan habitat yang baik untuk pelbagai spesies marin seperti siput, ketam dan teritip yang merupakan sumber makanan yang diperlukan oleh burung hijrah (Lefebvre \& Poulin 1996).

Selain itu, hasil analisis juga menunjukkan burung hijrah tetap bertumpu di kawasan Kuala Gula, Cabai Malai, Pulau Kalumpang, Pulau Selinsing dan Pulau Sanggar yang menjalankan pelbagai jenis aktiviti ekonomi meliputi hampir $40 \%$ daripada keseluruhan aktiviti ekonomi masyarakat setempat. Hasil analisis ini amat bertentangan dengan sifat semula jadi burung hijrah yang agak sensitif dan mudah terganggu oleh perubahan persekitarannya (Morrison 1986). Kawasan yang kurang menjalankan aktiviti ekonomi seperti Telok Kertang, Trong, Pulau Trong Selatan, Temerlok, Pulau Pasir Hitam dan Sungai Tinggi mencatatkan kedatangan burung hijrah terendah iaitu sebanyak 130 hingga 274 per $50 \mathrm{~m}^{2}$.

\section{PEMETAAN IKLIM}

Perubahan iklim diambil kira dalam kebanyakan kajian berkaitan burung hijrah kerana memberi kesan secara tidak langsung kepada penyediaan makanan dan mempengaruhi keadaan persekitaran (Thomas et al. 2004). Perubahan iklim sesuatu kawasan memberi kesan kepada tumpuan sumber makanan, taburan burung hijrah dan memandu burung hijrah dalam pemilihan lokasi habitat burung hijrah (Walther et al. 2002).

Hasil pemodelan iklim terhadap taburan burung hijrah yang melibatkan elemen suhu dan taburan hujan dalam kajian ini menunjukkan bahawa kepadatan taburan burung hijrah adalah berbeza-beza bagi setiap kawasan Hutan Paya 

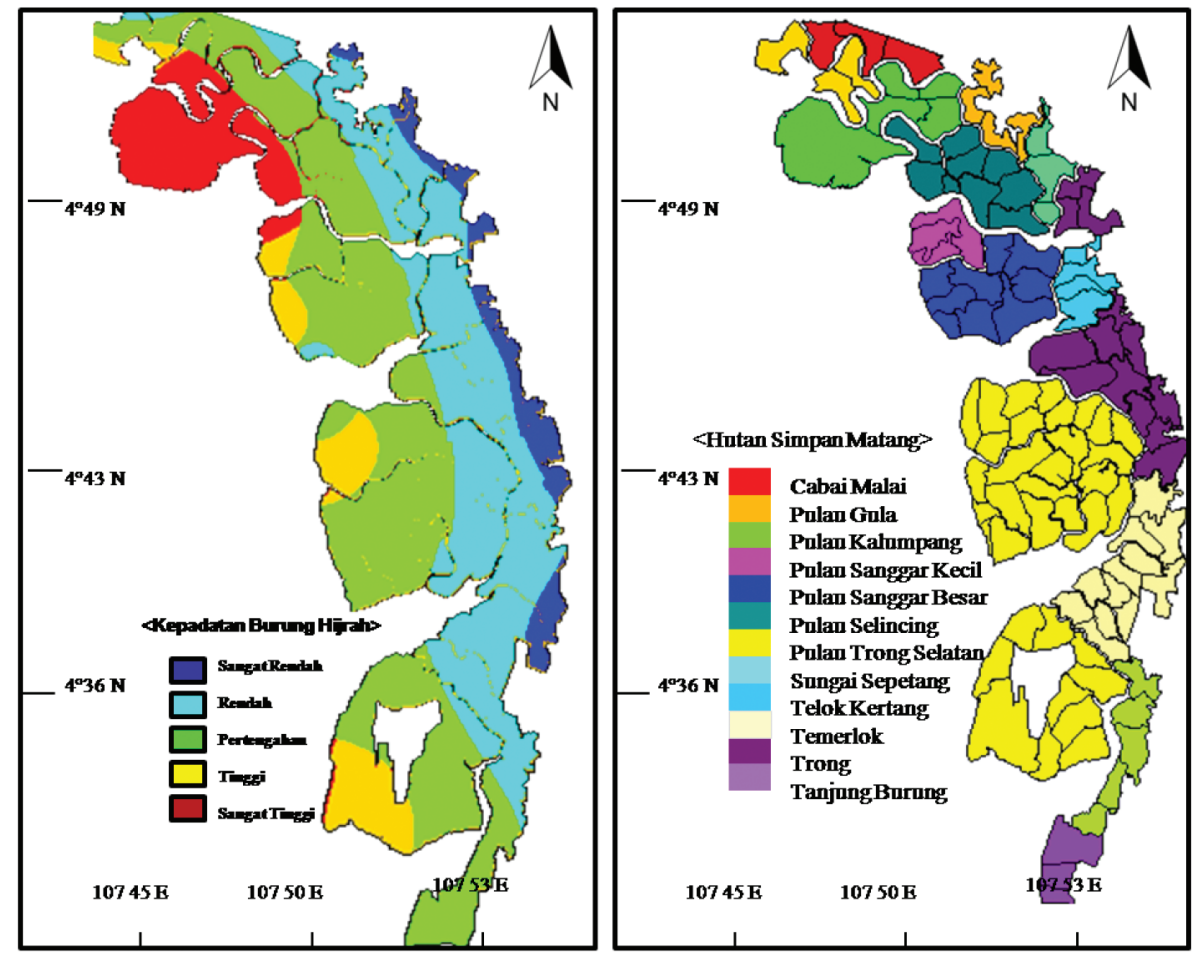

RAJAH 4. Pemetaan persekitaran
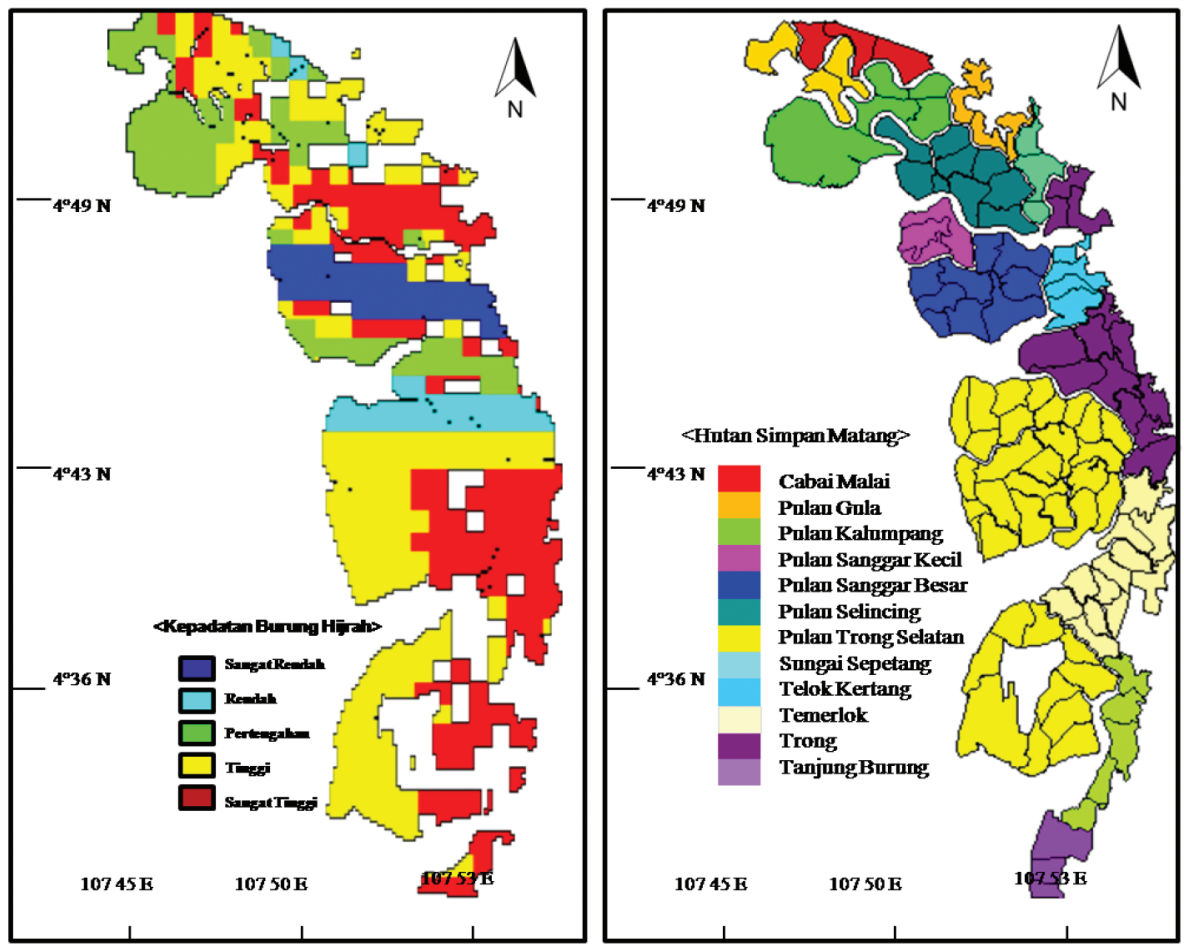

RAJAH 5. Kadar taburan hujan dan perubahan suhu

Laut Matang walaupun berada pada sempadan kawasan yang sama (Rajah 5).

Kepadatan taburan burung hijrah terhadap pengaruh iklim menunjukkan kawasan berhampiran daratan Hutan Paya Laut Matang mempunyai kadar purata suhu tahunan antara $26^{\circ} \mathrm{C}$ hingga $30^{\circ} \mathrm{C}$ dan purata taburan hujan tahunan antara 1040 hingga $1070 \mathrm{~mm}$. Kawasan sekitar Pulau Sanggar Besar dan Pulau Sanggar Kecil mempunyai kepadatan burung hijrah yang menunjukkan kadar kedatangan spesies burung ini pada tahap yang paling 
rendah berbanding kawasan lain dengan suhu persekitaran antara $20^{\circ} \mathrm{C}$ hingga $29^{\circ} \mathrm{C}$ dan purata taburan hujan tahunan antara 1030 dan $1060 \mathrm{~mm}$ (Rajah 6).

Hasil analisis yang diperoleh menunjukkan terdapat hubung kait antara perubahan iklim dan ketinggian kawasan. Hasil pemodelan menunjukkan kepadatan burung hijrah yang tinggi direkodkan bagi kawasan yang mempunyai ketinggian antara 500 dan $1500 \mathrm{~m}$ dari aras laut dan juga beberapa kawasan berhampiran tebing pada ketinggian antara 100 dan $300 \mathrm{~m}$ dari aras laut seperti kawasan Pulau Trong Selatan, Temerlok, Pulau Selinsing dan Pulai Pasir Hitam.

\section{PEMETAAN KETINGGIAN (TOPOGRAFI)}

Perbezaan ketinggian sekitar kawasan Hutan Paya Laut Matang turut memberi impak terhadap taburan burung hijrah dalam pemilihan habitatnya untuk mendapatkan makanan dan ruang rehat yang sesuai (Johnson \& Sherry 2001). Kawasan Hutan Paya Laut Matang mempunyai tebing hampir landai dengan purata ketinggian antara 0 dan $25 \mathrm{~m}$ dari aras laut. Sela ketinggian yang amat sedikit iaitu antara 20 hingga $40 \%$ daripada keseluruhan ketinggian menyebabkan setiap kawasan mempunyai kadar kenaikan air semasa pasang dan surut yang sama (Rajah 7).

Kawasan tebing sungai yang berlumpur lembut seperti Pulau Kelumpang, Pulau Sangga Kecil, Pulau Trong Selatan, Pulau Pasir Hitam dan Sungai Tinggi yang mempunyai ketinggian antara 0 dan 15 m menjadi tumpuan utama burung hijrah berbanding kawasan yang lebih tinggi iaitu pada ketinggian antara $25 \mathrm{~m}$ dan ke atas seperti Sungai Bahru, sebahagian Pulau Sanggar Besar dan Pulau Trong Selatan serta di sebahagian kawasan di Sungai Tinggi dan Temerlok menuju ke daratan (Rajah 8).

Kawasan tebing yang mempunyai tanah berlumpur lembut, sedikit berpasir dan basah menjadi pilihan lokasi carian makanan burung hijrah yang kebanyakannya mempunyai paruh yang panjang dan sederhana tipis dengan panjang paruh antara 1 dan $6 \mathrm{~cm}$ dan ketebalan antara 31 dan $36 \mathrm{~mm}$ yang mampu mendapatkan makanan jauh ke dalam lumpur. Hasil analisis ini menyokong kajian oleh Howes et al. (2003) yang menjelaskan bahawa spesies burung hijrah di asia banyak tertumpu di kawasan berhampiran tebing sungai untuk mendapatkan makanan.

\section{MENENTUSAHKAN PARAMETER TERPENTING}

Keadaan taburan burung hijrah terhadap pengaruh setiap parameter kajian adalah berbeza-beza. Oleh itu, menentusahkan parameter yang terpenting adalah penting untuk mengenal pasti ciri habitat yang diperlukan oleh burung hijrah (Boulinier \& Danchin 1997). Pengujian bagi mengenal pasti parameter terpenting dilakukan dengan memilih 4 stesen jaringan burung hijrah yang dipilih secara rawak iaitu Pulau Kalumpang, Pulau Sanggar Besar, Pantai Remis dan Sungai Tiang. Penilaian dilakukan berasaskan nilai kadar purata bagi populasi burung hijrah. Kadar purata yang diperoleh melalui hasil perbandingan saiz populasi daripada kerja lapangan dengan model parameter digunakan untuk mengenal pasti parameter yang terpenting dalam pemilihan habitat burung hijrah (Jadual 8).

Melalui kadar purata hubungan antara kesemua parameter kajian dan kepadatan taburan burung hijrah

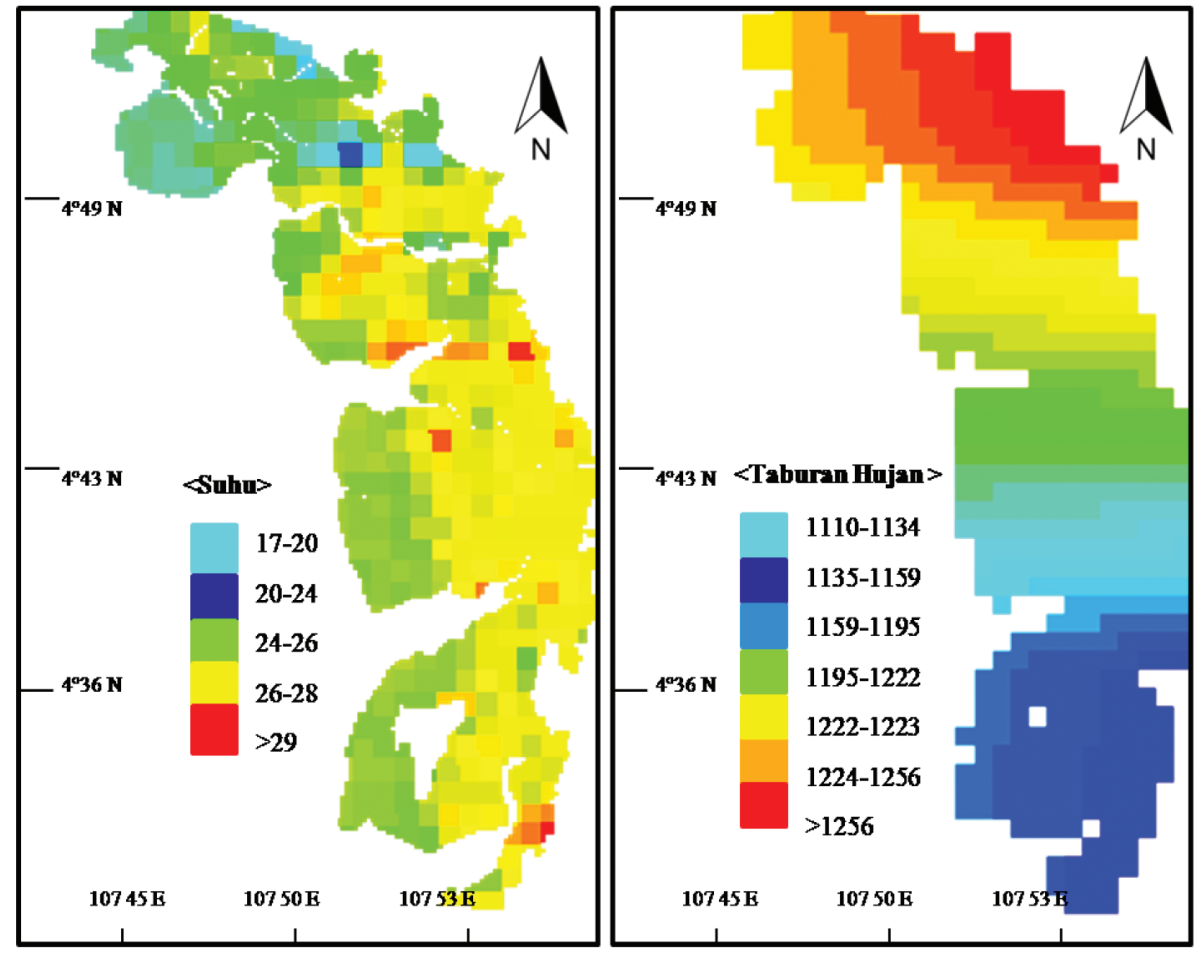

RAJAH 6. Pemetaan perubahan suhu dan hujan 

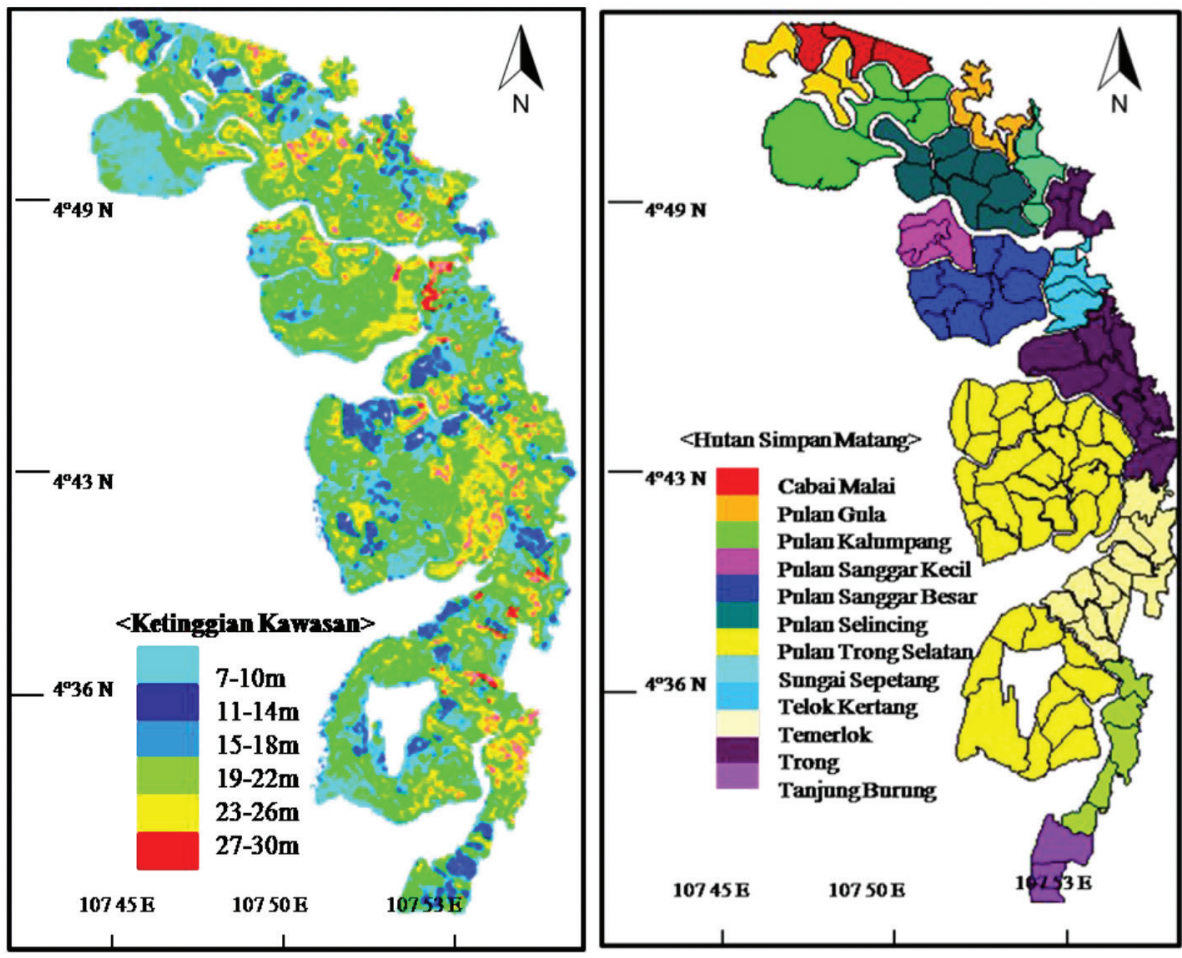

RAJAH 7. Kadar ketinggian kawasan

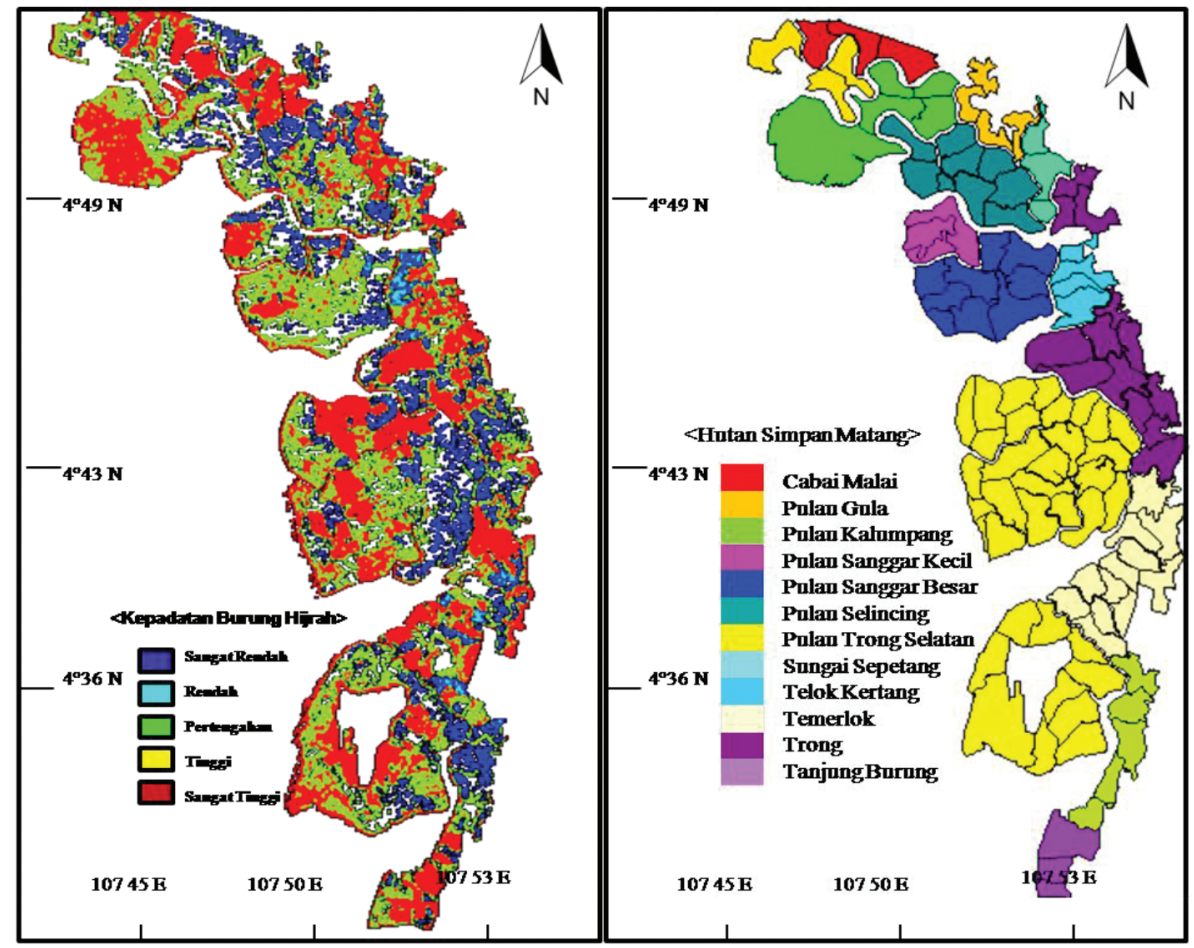

RAJAH 8. Pemetaan ketinggian kawasan

sekitar Hutan Paya Laut Matang yang diperoleh menunjukkan parameter topografi sangat mempengaruhi pemilihan habitat burung hijrah. Kadar purata sebanyak 1.03 iaitu melebihi nilai 1 diperoleh melalui hubungan antara parameter topografi dan kepadatan burung hijrah.
Parameter persekitaran menunjukkan hubungan terhadap kepadatan taburan burung hijrah melebihi nilai ramalan dengan kadar purata yang melebihi nilai 1 iaitu 1.09 dan parameter iklim menunjukkan nilai kadar purata yang kurang daripada nilai 1 iaitu 0.92 . 
JADUAL 8. Kadar purata nisbah kepadatan burung hijrah

\begin{tabular}{lccccc}
\hline $\begin{array}{l}\text { Ramalan kepadatan } \\
\text { populasi burung hijrah }\end{array}$ & $\begin{array}{c}\text { Pulau Kelumpang } \\
(\mathrm{P} 1)\end{array}$ & $\begin{array}{c}\text { Sangga Besar } \\
(\mathrm{P} 2)\end{array}$ & $\begin{array}{c}\text { Pantai Remis } \\
(\mathrm{P} 3)\end{array}$ & $\begin{array}{c}\text { Sungai Tiang } \\
(\mathrm{P} 4)\end{array}$ & Kadar purata \\
\hline Parameter topografi & 0.89 & 1.20 & 0.93 & 1.10 & 1.03 \\
Parameter persekitaran & 0.55 & 2.18 & 1.22 & 0.42 & 1.09 \\
Parameter iklim & 1.10 & 0.93 & 0.75 & 0.90 & 0.92 \\
\hline
\end{tabular}

\section{KESIMPULAN}

Hasil kajian yang dilakukan menunjukkan kepentingan pembinaan model habitat bagi burung hijrah menggunakan pendekatan Aplikasi Sistem Maklumat Geografi (GIS) dan Penderiaan Jauh dalam pemantauan spesies burung hijrah secara lebih bersistematik (Osborne et al. 2001). Pendekatan menggunakan kedua-dua aplikasi ini membolehkan hasil analisis yang lebih realistik iaitu menunjukkan gambaran keadaan sebenar taburan burung hijrah beserta pelbagai maklumat seperti tempat, jenis spesies dan corak taburan memudahkan pemahaman pengguna khususnya yang kurang kemahiran dan pengetahuan berkenaan pengurusan dan pengendalian data reruang (Bocco et al. 2001).

Aplikasi GIS berasaskan pendekatan piksel digunakan dalam kajian ini bagi menggantikan analisis titik yang banyak digunakan dalam kajian yang terdahulu (Lees \& Ritman 1991). Pendekatan berasaskan piksel membolehkan pengaruh setiap parameter dianalisis secara menyeluruh dan tidak tertumpu dalam lingkungan kawasan yang kecil sahaja (Jarvis et al. 2004). Pelaksanaan pemodelan menggunakan pendekatan GIS berasaskan piksel dalam kajian ini melibatkan gabungan beberapa data sokongan yang menggunakan perwakilan piksel dan data kajian lapangan (Ray et al. 2002).

Antara data piksel yang digunakan adalah data SRTM, TRMM dan MODIS. Penggunaan data berasaskan piksel dalam kajian ini dikenal pasti dapat mengatasi masalah kekangan dalam menganalisis dan memetakan sesetengah data kajian yang tidak dapat dianalisis secara tepat menggunakan data lapangan yang diperoleh (Dowding et al. 2004). Data SRTM sebagai contoh membantu dalam mengatasi masalah analisis dan pemetaan ketinggian kawasan sekitar Hutan Paya Laut Matang yang bertebing landai (Lehner et al. 2008). Selain itu, ketepatan data SRTM juga bersesuaian dengan kawasan kajian yang berskala besar seperti Hutan Paya Laut Matang (Gorokhovich \& Voustianiouk 2006).

Pemodelan habitat bagi kajian ini mengambil kira 6 parameter lapangan yang dapat dikelaskan kepada 3 kategori utama iaitu iklim, ketinggian dan persekitaran. Hasil analisis menunjukkan setiap parameter kajian memberikan kesan yang berbeza-beza terhadap taburan burung hijrah sekitar kawasan Hutan Paya Laut Matang. Dalam kajian ini, ketinggian kawasan menunjukkan parameter yang paling mempengaruhi pemilihan habitat burung hijrah yang kebanyakannya memilih kawasan berhampiran air sebagai lokasi pencarian makanan dan berehat (Moore et al. 1995). Hasil analisis melalui pemodelan ini secara tidak langsung memberi panduan kepada agensi yang terlibat dengan pemantauan dan perlindungan spesies burung hijrah seperti Jabatan Perhilitan berkaitan keperluan habitat burung hijrah.

Selain itu, kajian yang dilakukan ini dapat memperbaiki penetapan stesen jaringan oleh Jabatan Perhilitan yang sebelum ini lebih memberi tumpuan kepada kawasan sekitar Hutan Paya Laut Kuala Gula yang sehingga hari ini dikenali sebagai kawasan tumpuan spesies burung air termasuk spesies burung hijrah. Hasil pemodelan habitat yang dijalankan menunjukkan terdapat juga beberapa lokasi yang perlu diberi tumpuan berasaskan rekod kepadatan burung hijrah yang tertinggi dicatatkan sejak 10 tahun kebelakangan ini seperti kawasan Pulau Kalumpang, Pulau Trong dan Pulau Pasir Hitam.

\section{RUJUKAN}

Ahola, M.P., Laaksonen, T., Eeva, T. \& Lehikoinen, E. 2007. Climate change can alter competitive relationships between resident and migratory birds. Journal of Animal Ecology 76(6): 1045-1052.

Alongi, D.M. 2002. Present state and future of the world's mangrove forests: Environmental conservation. Foundation for Environmental Conservation 29(3): 331-349.

Bocco, G., Mendoza, M. \& Velázquez, A. 2001. Remote sensing and GIS-based regional geomorphological mapping - A tool for land use planning in developing countries. Geomorphology 39(3): 211-219.

Boulinier, T. \& Danchin, E. 1997. The use of conspecific reproductive success for breeding patch selection in terrestrial migratory species. Evolutionary Ecology 11(5): 505-517.

Dowding, S., Kuuskivi, T. \& Li, X. 2004. Void fill of SRTM elevation data-principles, processes and performance. In Images to Decision: Remote Sensing Foundation for GIS Applications, ASPRS, Fall Conf. Sep. 12-16, Kansas City, MO, USA.

Eng, C.T., Paw, J.N. \& Guarin, F.Y. 1989. The environmental impact of aquaculture and the effects of pollution on coastal aquaculture development in Southeast Asia. Marine Pollution Bulletin 20(7): 335-343.

Gauthreaux Jr., S.A. \& Belser, C.G. 2003. Radar ornithology and biological conservation. The Auk. 120(2): 266-277.

Gorokhovich, Y. \& Voustianiouk, A. 2006. Accuracy assessment of the processed SRTM based elevation data by CGIAR using field data from USA and Thailand and its relation to the terrain characteristics. Remote Sens. Environ. 104: 409-415.

Howes, J., Bakewell, D. \& Yus Rusila Nor. 2003. Panduan Studi Burung Pantai. Indonesia: Wetland International.

Jarvis, A., Rubiano, J., Nelson, A., Farrow, A. \& Mulligan, M. 2004. Practical use of SRTM data in the tropics-comparisons with digital elevation models generated from cartographic 
data. Working Document No. 198. Cali, International Centre for Tropical Agriculture (CIAT). p. 32

Johnson, M.D. \& Sherry, T.W. 2001. Effects of food availability on the distribution of migratory warblers among habitats in Jamaica. Journal of Animal Ecology 70(4): 546-560.

Lees, B.G. \& Ritman, K. 1991. Decision-tree and ruleinduction approach to integration of remotely sensed and GIS data in mapping vegetation in disturbed or hilly environments. Environmental Management 15(6): 823-831.

Lefebvre, G. \& Poulin, B. 1996. Seasonal abundance of migrant birds and food resources in Panamanian mangrove forests. The Wilson Bulletin 108(4): 748-759.

Lehner, B., Verdin, K. \& Jarvis, A. 2008. New Global Hydrography Derived from Spaceborne Elevation Data. EOS, Transactions American Geophysical Union 89(10): 93-94.

Li, Z.W.D., Bloem, A., Delany, S., Martakis, G. \& Quintero, J.O. 2009. Status of Waterbirds in Asia: Results of the Asian Waterbird Census: 1987-2007. The Netherlands: Wetlands International.

Mitchell, M.S., Lancia, R.A. \& Gerwin, J.A. 2001. Using landscape-level data to predict the distribution of birds on a managed forest: Effects of scale. Ecological Applications 11(6): 1692-1708.

Moore, F.R., Gauthreaux Jr., S.A., Kerlinger, P. \& Simons, T.R. 1995. Habitat requirements during migration: Important link in conservation. In Ecology And Management of Neotropical Migratory Birds, edited by Martin, T. \& Finch, D.M. New York: Oxford University Press. pp. 121-144.

Morrison, M.L. 1986. Bird populations as indicators of environmental change. In Current Ornithology, edited by Johnston, R.F. New York: Plenum Press. pp. 429-451.

Muda, A. \& Mustafa, N.M.S.N. 2008. A Working Plan for the Matang Mangrove Forest Reserve, 5th ed. Perak: State Forestry Department of Perak Darul Ridzuan.

Osborne, P.E., Alonso, J.C. \& Bryant, R.G. 2001. Modelling landscape-scale habitat use using GIS and remote sensing: A case study with great bustards. Journal of Applied Ecology 38: 458-471.

Rahmah Mahmud. 2009. Laporan Jaringan Burung Hijrah bagi kawasan Kuala Gula. Jabatan Perhilitan cawangan Wilayah Persekutuan.
Ray, N., Lehmann, A. \& Joly, P. 2002. Modeling spatial distribution of amphibian populations: A GIS approach based on habitat matrix permeability. Biodiversity \& Conservation 11(12): 2143-2165.

Richards, J.A. \& Jia, X. 1999. Remote Sensing Digital Image Analysis: An Introduction. 3rd ed. Berlin, Heidelberg, New York, London, Paris, Tokyo, Hong Kong: Springer-Verlag.

Rouget, M., Richardson, D.M., Cowling, R.M., Lloyd, J.W. \& Lombard, A.T. 2003. Current patterns of habitat transformation and future threats to biodiversity in terrestrial ecosystems of the cape floristic region, South Africa. Biological Conservation 112(1): 63-85.

Schaub, M., Pradel, R., Jenni, L. \& Lebreton, J.D. 2001 . Migrating birds stop over longer than usually thought: An improved capture-recapture analysis. Ecology 82(3): 852-859.

Studds, C.E. \& Marra, P.P. 2004. Nonbreeding habitat occupancy and population processes: An upgrade experiment with a migratory bird. Ecology 86(9): 2380-2385.

Thomas, C.D., Cameron, A., Green, R.E., Bakkenes, M., Beaumont, L.J., Collingham, Y.C. \& Williams, S.E. 2004 Extinction risk from climate change. Nature 427(6970): 145-148.

Walther, G.R., Post, E., Convey, P., Menzel, A., Parmesan, C., Beebee, T.J.C., Fromentin, J.M., Hoegh-Guldberg, J.M. \& Bairlein, F. 2002. Ecological responses to recent climate change. Nature 416(6879): 389-395.

Pusat Pengajian Sains Kajihayat

Universiti Sains Malaysia

11800 USM, Pulau Pinang

Malaysia

*Pengarang untuk surat-menyurat; email: azimahilyasa@gmail. com

Diserahkan: 1 September 2014

Diterima: 4 Mei 2015 